\title{
G.D. Grebenshikov humane pedagogics
}

\author{
S.M. Pinaev ${ }^{1 *}$, E.K. Ametova ${ }^{2}$, and S.S. Tsaregorodtseva ${ }^{3}$ \\ ${ }^{1}$ Russian University of Peoples' Friendship, Moscow, Russia \\ ${ }^{2}$ V.I. Vernadsky Crimean Federal University, Simferopol, Russia \\ ${ }^{3}$ V.I. Vernadsky Crimean Federal University, Simferopol, Russia
}

\begin{abstract}
Stating the problem. Time is the best measure of creativity evaluation. It ruthlessly and objectively separates the wheat from the chaff. Only real literature can stand the test of time. Georgiy Grebenshikov's talent was noticed from the very beginning of his creative work. He was highly acknowledged by A.M. Gorkiy, V.K. Korolenko, V.Y. Shishkov, F.M. Shalyapin, I.I. Sikorskiy, N.K. Rerih and others. However his author fate was not always even and smooth. He has spent the most part of his life far from his Motherland. This fact saved the writer from inevitable repressions and at the same time was his tragedy. In one of his letters he admitted that if a dog from his Motherland came, he would kiss it. Immigration has divided his creative work into two periods: Siberian 19061920 and Immigration 1920-1956.
\end{abstract}

\section{A problem statement}

The main saga 'The Churaevs'" by Grebenshchikov was critically acclaimed by A.A. Makarov, V.A. Rosov, B.B. Mamraev, T.G. Chernyaeva, M.G. Nikitina, O.G. Levashova; of particular interest are the reviews by A.P. Kazarkin and K.V. Anisimov on Grebenshchikov's early and mature achievements. A.P. Kazarkin analyzed in detail the Siberian context of all seven published volumes of the novel and identified the origins of Grebenshchikov's work [1]; at the genre and style level, Kazarkin also considered the literary connections of 'The Churaevs' with the classics of Russian and Soviet literature: the novels 'The Brothers Karamazov' by F.M. Dostoevsky, 'War and Peace' by L.N. Tolstoy, 'The Artamonovs' Case' by Maxim Gorky, 'The Road to Calvary' by A.N. Tolstoy, and others [2]. K.V. Anisimov examined the creative history of 'The Churaevs' in the context of Young Siberian prose and defined Grebenshchikov's novel as the 'summit text' of the literary group, which included A.E. Novoselov, A. Zhilyakov, S. Isakov, V. Bakhmetyev, I. Goldberg, and others [3].

The studies of A.Yu. Gorbenko on arrangements of Grebenshchikov's life turned out highly controversial; in his works, Gorbenko attempted to reveal the contextual connections of the texts of Lev Tolstoy and Grebenshchikov [4], and also identify some evangelic reminiscences in 'The Churaevs' novel [5].

*Corresponding author: prof-ped.gpa@mail.ru 
Of undoubted interest are publications by the Russian diaspora critics devoted to the topic (I. Savchenko, P. Balakshin, V. Maevsky, A. Zhernakova-Nikolaeva, P. Kovalevsky, M. Slonim, O. Duboklyar, N. Logunova, V. Bulina, F. Kubansky, V. Kovarskaya, and others).

P. Balakshin wrote wisely in his articles on the universal nature of 'The Churaevs' noting the author's righteousness while urging 'make way toward the truth as lions.' However, according to Balakshin, Grebenshchikov's epic 'has fundamentally disagreed with the plan' and has no future, since to say that 'Russian universality has been achieved through the world dispersion of millions of Russian emigrants is to mock over own fate' [6]. Grebenshchikov did not agree with this understanding of the main idea of his novel; in a letter to Balakshin, Grebenshchikov advised reading his 'Messenger. Letters from Pomperag', which should complement the better understanding of the idea of 'The Churaevs'.

In 1956, the Russian diaspora in the United States solemnly celebrated the 50th anniversary of the literary activities of G.D. Grebenshchikov. Numerous publications spoke of the great importance of 'The Churaevs' novel for the development of Russian literature. According to Olga Duboklyar, it 'will serve as a valuable material for future generations of scientists and historians in the study of our era and the Russian people', because the main message that Grebenshchikov sends to his readers is that "nothing lasts forever, Carthage fell, and so did Babylon, only the disseminator (sower) is eternal ...' [7]. Duboklyar also develops the idea that common people used to be perceived as ignorant peasants and drunkards; a simple person in Grebenshchikov books is shown as a man of many talents, these people are capable of being wise and God-fearing, naive and affectionate, subtle and inventive, sometimes rude but crafty. According to F. Kubansky, it was precisely the interest in the common people, the realism of their image that was the reasons that Grebenshchikov was not highly appreciated abroad, where 'the first place was occupied by the literature about 'noble people' and not about people of all Russia' [8].

One of the most interesting among the anniversary publications was 'The Bard of Siberia' by A. Zhernakova-Nikolaeva, who wrote about the seventh volume of the novel 'Kissing the Serpent' noting the 'author's brilliant talent' and the genuine Russian spirit, which 'permeates and fancies the entire work' [9].

These contradictory assessments of the Russian diaspora were voiced mostly by journalists and critics; a complete literary analysis of the multivolume novel 'The Churaevs' has not yet been done in both Russian and foreign science.

Research shows that nearly half a century passed. These were the years of oblivion of the writer's books that did not match ideological canons of social realism. Having been read at last G.D. Grebenshikov's works reflected the fate, having been lived by the nation during Revolutionary years, Civil war and Great Patriotic war. His works' characters had drunk the cup of suffering completely at the Motherland and in banishment, they experienced expiation of guilt to their faith in Man's future.

\section{Results of the research}

Georgiy Dmitriyevich was born not far from village Shemonaiha of East-Kazakhstan region at Nikolayevskiy mine (after renaming Kamenevka) in a poor many children family. His father, Dmitriy Lukich (1844-1920) was working as a flat trimmer at the mine and since 1888 as a farmer. G.D. Grebenshikov's mother Yelena Petrovna (1850-1920) has played an important role in his fate. She was a dreamer and a prayer. She was very religious and in spite of hard life conditions she preserved the ability to dream and see the beauty of the world. G.D. Grebenshikov has confessed that his mother was the most wonderful and saint vision of his childhood [10]. 
Yelena Petrovna often told fairy tales to children, sang simple songs very well. And in such moments little Yegorka has seen something colorful and some invisible cities...His mother treated Yegor specially, as he was the most tender and affectionate of her sons. In his autobiographic works he remembered with gratitude that it was his mother who insisted that he studied a lot and escaped the poverty and exacerbation that was inevitable in backbreaking conditions of Nikolayevskiy mine. At school Yegor Grebenshikov could study incomplete 4 years. He came to the first class in "his mother's high boots and father's cap and his brother's coat".

His classmates at the beginning made fun of him, but he succeeded in his studies a lot. He did sums to merchant's sons in exchange for sweets and read a lot. In 1894 his father took him for forest harvesting operations and he did not complete his fourth year examination. When Gera was 12 (he was called like this in his family) he worked in Semipalatinsk as a dish washer, a chemist assistant and a nurse. In 1898 his father took him to forestry in Shemonaiha, where Georgiy helped the forester and read a lot. It was here where he read "Hunter's notes" by I. Turgenev after which he had seen the nature around him quite differently. He wrote about that in his autobiography as an accomplished miracle: «I fell to "Hunter's notes" and it was like a patch came off my eyes. All this blooming nature - here it is behind the window, behind the river Uba. How could I not see it! Before it was for me only "a field" with hard work. And now for me it is a beautiful divine garden. From here his curiosity to life, nature, literature that in the following ten years made a writer-beginner of me» [11].

In future a talented young man became a clerk with magistrate P.Y. Tsvilinskiy in Shemonaiha. Peter Yevstafjyevich Tsvilinskiy was a good lawyer, a cultural and erudite person. He was a member of Russian Geographical Society of Semipalatinskiy subdivision. Having lived in his family, Grebenshikov listened to instructions of judge's prim aunt, he read a lot and learned the rules of behavior in the society. In 1902 a notary from Semipalatinsk invited Georgiy Grebenshikov to work as a senior clerk with decent salary. He agreed, bought a farm $45 \mathrm{~km}$ from the city, brought his parents there and got married.

G.D. Grebenshikov's first literary experiences refer to 1904-1905 in newspaper "Semipalatinsk paper" under pseudonym "Peasant G-s". In April 1906 Georgiy Dmitriyevich first book "Siberian outskirts echos" was published. There was an advertisement in "Semipalatincki paper" on July, 25, 1906: There is a new book for sale "Siberian outskirts echos" in Kosarev shop. First stories by Georgiy Grebenshikov. The price is 40 kopeks".

Having become a mature writer and later a publisher G.D. Grebenshikov did not remember about this his not very successful literary experience and named his first work "Vasyutkin holiday. Christmas story" (1906). The title and subtitle of the story are intended for a trustful reader, who instead of a light holiday have known about a widow's death, a mother of three children, who decided to go for alms with a baby, hoping for people's generosity on Christmas days, but she lost her way and had frozen.

Pain for impenetrable misery in the village will often be in early creative works of G.D. Grebenshikov whose childhood was very similar to this one of Vasyutka [10].

In 1906 having visited one of Ust-Kamenogorsk schools he wrote an essay "At one school". This school was located in a small and dirty hut and children did not study properly in it.

The interest to the creative work of a famous Siberian writer Georgiy Dmitriyevich Grebenshikov (1884-1864) has risen a lot during the last years. And when his back file was returned to Russia, active research of his remains has started.

In the writer's record there is correspondence and life publications, devoted to Grebenshikov's creativity, by critics of Russian foreign: G. Struve, I. Savchenko, P. Balakshina, V. Mayevskiy, A. Zhernakova-Nikolayeva, P. Kovalevskiy, M. Slonima, O. 
Dyuboklyar, N. Logunova, V. Bulina, F. Kubankiy, V. Kovarskiy; Grebenshikov creative links became known. It became a base for literary study works, his publishing and cultured activity was researched; conclusions about his world outlook orientations close to philosophy of Russian cosmism. In this article an attempt is made to describe his pedagogical activity.

This has become the basis for literary works. As for Grebenshikov publishing and culture creating activity; conclusion was made about his outlook values close to the philosophy of Russian cosmism. An attempt to describe his pedagogical activity was made in this article.

Grebenshikov has lived in the USA (Florida) from 1940 to 1954 and was teaching at Lakeland college (Florida). The fact that he has changed his life so abruptly at such age (he was in his fifties) was both accidental and regular. Grebenshikov arrived in Lakeland to give a lecture about Siberia and make a presentation of his book «The Turbulent Giant» to the students.

According to G. Grebenshikov memories, college has organized a lecture but he was given too little time and there was some confusion with slides. His wife Tatjyana Denosivna was helping him with slides. So his wife and him considered this lecture a fail and were ready to leave. But to his greatest surprise, he was offered a constant job at a university college - to give lectures on world literature instead of a sick professor Barnet. He had to make the decision immediately and start working the same day. Grebenshikov had only one hour and a half to prepare for the lecture. The rector did not have any doubt about him, he saw a good qualified lecturer. Dean Dilmelt offered Grebenshikov to get ready for his lecture at university library and devote it to Russian classic literature.

Indeed Grebenshikov was an experienced lecturer and by that time he has already travelled all around America with lectures about Siberia. According to Tatjyana Denisovna words, he had given about 600 lectures already by that time. In 1936 Grebenshikov wrote to Bunin that he is giving lectures in the USA colleges in English: "I am rushing from one end to another along all America. I have broken the third car already. I have driven 130000 miles for 9 years" [11]. Lectures about Siberia represented a detailed history of Siberia reclaiming. As a program of one of them testifies that was preserved in his record, he was lecturing in the following order:

1. The first introductory lecture "About Siberia conquest and colonization by the Russians".

2. The second lecture "Siberian ways and roads".

3. The third lecture "Dozing beauty".

4. The fourth and final lecture "Siberian treasures".

Today we can have a good idea about those lectures as a book "My Siberia" was published using these materials.

But one thing is to give a well-prepared lecture in front of a new, but very interested audience and another thing is to create a cycle of lectures, having included them into the system of teaching a course. It took Grebenshikov a lot of efforts and commitment to improve his knowledge.

In 1945 after 5 years of his successful work at the university he was awarded a doctor degree. By this he has proved that he was named Siberian Gorky not in vain. He also did not have higher education and became a PHD having studied before only for three years at a parochial school and listening to lectures at Tomsk university.

Evidently his talent, creative abilities combined with good will, hard work and aspiration to knowledge should be taken into account. American democracy also should be pointed out that Grebenshikov was awarded a degree. For example, during the times of Tsar Russia Gorkiy was awarded an honorary title of academician because of his polite 
literature, but in 1902 Nickolay II ordered to cancel it (as a protest A.P. Chehov and N.G. Korolenko also left the Academy).

Grebenshikov managed to become not just an ordinary professor with a degree, but one of the best and the most favorite among the students and faculty of the university. Very many students registered for his courses, Usually only 25 students were allowed at a time, but he usually had 30-35.

Lakeland college is still proud of the fact that a famous writer G.D. Grebenshikov was teaching literature, history and a special course in literary creative art. In his essay «Hitch your waggon to a star» Grebenshikov told in detail about his teaching at college, about priceless experience that he had during the years of his work and also about the peculiarities of his approaches.

Grebenshikov mentioned that not only strong students registered for his courses but also those who did not like to read and go to the library. But even during the first classes they became active and interested participants of the education process as Russian professor's classes were conducted in the form of literary holidays: scenes from Chekhov's plays were performed, Pushkin's poems were recited; Russian songs were sung in chorus. Russian literature class was attractive because everybody could show his talent there. Grebenshikov has never read his lectures from the paper because he said that "every professor who loves his students should have one more military strategy: involve students in work so that to sit and listen himself" [10].

Nowadays it would be defined as innovative approach with the use of interactive teaching methods and Grebenshikov just considered that he is trying "to teach those young people using every possible way". For example, to prepare the class to percept L.N. Tolstoy novel "Anna Karenina", he asked the eldest student in class who already had grown up children to tell about her first kiss. At first the woman was embarrassed but then she timidly started her story and nicely transformed. Grebenshikov remembers: "We were all admiring her and saw how her face became younger and transformed not only former beauty but also a beautiful image of innocence, shyness and the phenomenon that returns from the past as a picture of skillfully executed medallion of the past century".

After her story everybody was looking at her with other new eyes and nobody protested against the assignment to tell about his early love story. The assignment was not obligatory for everybody but during the next class there were a lot of volunteers to read their stories and the professor "enjoyed the stories and most of all those nice faces and already so close to him and he has learnt a lot from them". And then the class passed on to the discussion about "Anna Karenina" novel. Grebenshikov was making interesting historical comments.

Thus through experiencing their own feelings and joining the history Russian professor led American students to women psychology perception and solution of mysterious Russian soul of Tolstoy's characters.

Grebenshikov was constantly looking for new and non standard in teaching, he could not stand boredom and routine at his classes. His favorite course - "Creative writing" or as he called it literary laboratory. This course was an authorial one and really experimental. It was approved by the rector specially for Grebenshikov. During the first class he warned the students:

- I do not promise to make you writers or poets. You should be born a poet, but we will learn to THINK together.

He always started his classes in a non traditional way, according to modern definition with the creation of a problem situation. For example, at one of the classes of his creative laboratory he started from a bright introduction: "There was time on this planet when its inhabitants did not have any words to talk to each other. But they had some language that consisted exceptionally of vowels and interjections. There were groans, snores, hisses but there were no words yet. The longest word consisted of only one syllable. It appeared when 
our primogenitors were already capable of living in caves. Evidently it was the syllable "ma". Repeating the syllable we received our word "mama".

And then the lecturer asked a dozing student who has just come from work: did we inherit anything from a caveman or not?

The student answered impudently: how could professor think that we could learn something from a caveman. Another student supported Grebenshikov, arguing that we inherited the most important property from a caveman - the fire that he carried through ice ages, but the most valuable is that a caveman has created the first alphabet which is used now by all the peoples in all the countries.

A wisecracker Pete began to participate in the discussion and pronounce imitative words:

- Hey! Ah! Oh! Sh! Cock-a-doodle-doo!

Grebenshikov remembered that it was "funny and infectious and several young guys joined him, then some girls also joined them and the whole class filled with terrible animal roar and his, whistle and growl" [10].

During this class Grebenshikov had to raise his voice "because it became silent in the neighboring rooms: they were alarmed by this sudden wild roar".

- You see, I addressed the class. Alphabet and interjections that we inherited from cavemen have not yet made us humans. You can easily see yourself how easily we become animals?

Students taking part in whistling, roaring and growling shocked students began to hiss more humanely, restoring the silence in which I managed to finish the appeal.

- The word has made us not only humans but also civilized people. This word now distinguishes a human from an animal.

And then students have written down: "One of the most invaluable culture treasure is the word. This is a wonderful charisma. It has its own history, historical and logical evolution. We must value the Word and not chuck it away. We should not spoil the Word by murmuring in our speech and always pronounce it with special respect. This is a delightful instrument to express our thoughts by music sounds whether we pronounce it orally or sowing white paper leaves with it.

The word heedlessly let from the mouth, false or evil, always hits not the goal but us. Any phrase especially written one but dignified by a thought is not only useless and petty but also harmful and more often dangerous. That is why first of all we should learn the art to pronounce and write the Word, the art to hear it, the art to read, understand and evaluate the meaning of art in the Word and Word in the art.

Evaluation ability of any art should include the feeling of gratitude to everybody whom we are obliged for the fact that we have inherited from the past not excluding the first primeval husbandman. This feeling of gratitude is the most noble feeling helping to exalt our own thoughts, escape a dangerous way of vulgarism in the Word and Business; raise from chaos of destructive forces to the heights of inspirational creative work".

\section{Conclusions}

Only a talented creative teacher can teach the students creative art. What kind of works could students write at such classes? Unexpectedly the answers to these questions were received from Japan an Orientalist, the secretary of Bibliophile Association (1993-1995) Vasiliy Molodyakov (a doctor of political sciences, Takushoku university professor). He has a collection of students' works of Creative Writing Workshop), that Grebenshikov was teaching in 1941/42 academic year. The publication of 10 short students' works was introduced by Grebenshikov. 
The years of work at college were relatively financially sound so he could pay all his debts on publication projects in Churayevka ("Russian Village"). Tatjyana Denosivna was working at that college as a publishing house director and they helped many Russian writers in Europe, sent them some food parcels, contributed to publications in the USA.

During the war many students were poor, they had to work and come to classes very tired and hungry, there were former war stockade prisoners. Grebenshikov could not stay indifferent to poor students, and he paid the tuition for seventeen of them. To receive professor Grebenshikov scholarship you should write and speak Russian. The Grebenshikovs considered one of the students Stephan Beskind their stepson. He was an immigrant from Ukraine and they adopted him and called him Stepushka. On the 14th of February 1945 Grebenshikov has written in his letter to him together with the blessing the Rules of Life:

1. Walk with God Truth, do not count on human truth. God Truth is placed in your heart in the form of love, conscience, lust for beauty and happiness. Without spiritual inspiration a man can never be really happy.

2. Start judging other people with judging yourself fist. That is before judging the others ask yourself if everything is perfect in you. That is why lessen the drawbacks of the others and increase your own benefits. Try to find in the worst man something good and you will always find it and it means that even the worst person while communicating with you will become better. God has given you a light of sense and love and their rays should always keep warm the others.

3. Choosing a companion for yourself - a wife, do not be tempted by external beauty only, but look for the beauty of the heart, mind and hard work. Having married be faithful to your wife till the last days and when you have children teach them from the young age to labor, need, yes, to need so that they would value everything from God gifts and the wealth of experience. Remember that children who do not know what need is will be poor having millions.

4. Choose a definite way for yourself or some big idea for achievement and follow this way without deviation persistently not losing your heart while failures: good luck spoils us and failures teach.

His step father instructions have become a life program for Stephan Beskind.

Grenbenshikov teaching success is explained by the fact that he insisted on humane pedagogy principles and he was always ready for the dialogue with students and he has never hidden the fact that he was learning a lot from them. Teaching was a process of creativity for him, the skill to lead up the ladder, leading downstairs". The name of a great pedagogical novel by Bella Kaufman has something in common with the title of Grebenshikov pedagogical essay "Hitch your wagon to a star".

\section{References}

1. A.P. Kazarkin, The motifs of Dostoevsky in the novel by G. Grebenshchikov 'The Churaevs' (Tomsk State University publishers, 2004)

2. A.P. Kazarkin, Siberian regional epic, The Siberian text in Russian culture (2002)

3. K.V. Anisimov, Siberian regionalism and G.D. Grebenshchikov's novelism: on the interpretation of some motives of the novel 'The Churaevs' (Part I), Altai Text in Russian Culture (2004)

4. A.Yu. Gorbenko, Georgiy Grebenshchikov as Lev Tolstoy: Tolstoyan Text of G. Grebenshchikov's Arrangement of Life, Altai Text in Russian Culture, 99-113 (2015) 
5. A.Yu. Gorbenko, Vasily Churaev and John the Apostle: features of evangelical mythology in the novel by G.D. Grebenshchikov 'The Churaevs', Proceedings of Krasnoyarsk XII Christmas educational readings. Krasnoyarsk, 33-38 (2012)

6. P. Balakshin, Shaman in patent leather boots, Sovremennik, 30(31) (1976)

7. O. Duboklyar, Golden anniversary of G.D. Grebenshchikov as a writer (1956)

8. F. Kubansky, Russian hideaway in Washington country, Novaya Zarya, 22 (1956)

9. A. Zhernakova-Nikolaeva, The Bard of Siberia, Vozrozhdenie, 52 (1956)

10. G.D. Grebenshikov, My Siberia. - Barnaul, Altay State university publishing house (2002)

11. A letter of G.D. Grebenshikov to I.A. Bunin, Russian backfile in the city of Leeds (Great Britain) MS/ 1066/2876 